\title{
Expression of 5-fluorouracil-related enzymes in lung cancer: ELISA characterizes enzyme activity and messenger RNA expression
}

\author{
MASANORI TSUCHIDA ${ }^{1}$, YASUSHI YAMATO ${ }^{2}$, TAKEHISA HASHIMOTO ${ }^{1}$, HIROHIKO SHINOHARA ${ }^{1}$, \\ HAJIME UMEZU $^{3}$, KATSUO YOSHIYA ${ }^{2}$, TERUAKI KOIKE ${ }^{2}$ and JUN-ICHI HAYASHI $^{1}$ \\ ${ }^{1}$ Division of Thoracic and Cardiovascular Surgery, Niigata University Graduate School of Medical and Dental Sciences; \\ ${ }^{2}$ Department of Thoracic Surgery, Niigata Cancer Center Hospital; ${ }^{3}$ Department of Clinical Pathology, \\ Niigata University Medical and Dental Hospital, Niigata, Japan
}

Received September 22, 2008; Accepted December 2, 2008

DOI: 10.3892/or_00000321

\begin{abstract}
The enzymes thymidylate synthase (TS), dihydropyrimidine dehydrogenase (DPD) and orotate phosphoribosyl transferase (OPRT) are involved in the metabolism of the anticancer drug 5-fluorouracil (FU). Expression of TS, DPD and OPRT in cancer tissue has been reported to be associated with sensitivity and/or resistance to 5-FU therapy. However, the role of TS, DPD and OPRT expression in lung cancer has not been fully established. Furthermore, among several measuring methods, it is not clear which method effectively predicts the response to 5-FU therapy. The aim of this study was to analyze the expression of 5-FU-related enzymes using enzyme-linked immunosorbent assay (ELISA) and to examine the correlation of ELISA and the results obtained using different measuring methods such as reverse transcript polymerase chain reaction (RT-PCR), immunohistochemistry, and enzymatic activity. Lung cancer specimens were obtained from 134 patients who underwent curative resection for lung cancer. As a pilot study, enzyme expression of 11 samples was measured using 4 different methods for DPD: RT-PCR, immunohistochemistry, enzymatic activity and ELISA. The relationships between pairs of results were compared, and then enzyme protein expression was measured using ELISA in 119 patients with adenocarcinoma. Of the 4 independent methods, the highest correlation was observed between protein expression measured by ELISA and enzyme activity. The correlation of gene expression and ELISA was also
\end{abstract}

Correspondence to: Dr Masanori Tsuchida, Division of Thoracic and Cardiovascular Surgery, Niigata University Graduate School of Medical and Dental Sciences, 1-757 Asahimachi-dori, Chuo-ku, Niigata 951-8510, Japan

E-mail: kentsuchi@hotmail.com

Key words: thymidylate synthase, dihydropyrimidine dehydrogenase, orotate phosphoribosyl transferase, enzyme-linked immunosorbent assay, lung cancer significant. The protein level in stage I adenocarcinoma measured using ELISA was $13.0 \pm 24.8 \mathrm{ng} / \mathrm{mg}$ protein for TS, $362.2 \pm 264.3 \mathrm{ng} / \mathrm{mg}$ protein for DPD and $4.5 \pm 2.0 \mathrm{ng} / \mathrm{mg}$ protein for OPRT. The predictive value of the enzymes for prognosis and the effectiveness of 5-FU was not determined as few recurrences were observed during the short follow-up period. In conclusion, ELISA is a simple and reliable method to measure key enzymes related to 5-FU therapy.

\section{Introduction}

Although 5-FU chemotherapy has been widely used in the treatment of various cancers, the role of 5-FU therapy in lung cancer has not been established. Since several large scale or meta-analysis studies have proven the survival benefit of tegafur-uracil (UFT) in patients following surgery for pathological stage I adenocarcinoma (1-3), the administration of UFT has become a standard therapy after curative resection in lung cancer. Therefore, the determination of gene and protein expression levels of enzymes related to 5-FU therapy in cancer tissue is now of great interest for predicting the effect of chemotherapy. Thymidylate synthase (TS) is an integral enzyme in DNA biosynthesis, where it catalyzes the reductive methylation of deoxyuridine monophosphate (dUMP) to deoxythymidine monophosphate (dTUMP) and provides the only route for de novo synthesis of pyrimidine nucleotides within the cell (4). Dihydropyrimidine dehydrogenase (DPD) is the first, and rate-limiting, enzyme for the catabolism of 5-FU $(5,6)$. High DPD mRNA levels have been found in various human cancers and cell lines with low sensitivity to 5-FU. The predominant pathway of 5-FU anabolism occurs via orotate phosphoribosyl transferase (OPRT), which converts 5-FU to the nucleotide form in one step. OPRT has also been shown to correlate with tumor sensitivity to $5-\mathrm{FU}$ (7).

There have been numerous studies demonstrating the predictive value of 5-FU-related enzymes in gastrointestinal cancers. Both high TS mRNA, quantified by RT-PCR, and high TS protein expression, quantified by immunohistochemical staining of the cancer tissue, has been shown to predict a poor response to fluoropyrimidine-based therapy for colorectal cancers. Ichikawa et al (8) and Salonga et al (9) 
reported that patients with both low DPD and low TS mRNA expression in primary colorectal cancers responded to 5-FUbased chemotherapy, and Fujiwara et al (10) reported that sensitivity to 5-FU was only noted in samples with low TS and DPD mRNA expression levels in human gastric cancer. With respect to the predictive value of these markers in lung cancer, several studies reported that TS, DPD and OPRT expression quantified by mRNA expression obtained from fresh frozen samples or protein expression quantified by immunohistochemical study may predict the response to 5-FU therapy (11-15). However, there is still no consensus regarding the clinical utility of these markers. Even in gastrointestinal cancer, the American Society of Clinical Oncology stated that 'data are insufficient to recommend the routine use of p53, ras, thymidine synthase, dihydropyrimidine dehydrogenase, thymidine phosphorylase, microsatellite instability, 18q loss of heterozygosity, or deleted in colon cancer protein in the management of patients with colorectal cancer' (16). Confusion may be partially due to lack of a standard method for enzyme evaluation. For example, controversies exist in the standardization of immunohistochemical assessments for protein localization, the scoring methods and the cut-off values to determine positive staining. Furthermore, messenger expression does not always represent protein expression and functions. In fact, the relationship between gene expression and protein level or enzyme activity has not been clearly explored. Thus, a simple and reliable method using small samples is required for prediction of response to 5-FU therapy.

To establish the role of protein expression measured using enzyme-linked immunosorbent assay (ELISA), lung cancer tissues were analyzed by RT-PCR, immunohistochemistry, enzymatic activity and enzyme immunoassay, and the relationships between pairs of results were compared. Finally, protein levels of TS, DPD, and OPRT were measured using ELISA in 134 lung cancer samples.

\section{Materials and methods}

Patients. Lung cancer specimens were obtained from 134 patients who underwent curative resection for lung cancer $>2 \mathrm{~cm}$ in size at Niigata University Hospital and Niigata Cancer Center Hospital. The institutional review committee of Niigata University approved the study protocol, and written informed consent was obtained before surgery from each patient. As 5-FU therapy for lung cancer has been observed to be effective in stage I adenocarcinoma $>2 \mathrm{~cm}$ in diameter $(1,2)$, protein expression was measured in patients who were suspected to have clinical stage I adenocarcinoma $>2 \mathrm{~cm}$. The histology of the tumor was finally diagnosed as adenocarcinoma in 119, squamous cell carcinoma in 10, large cell carcinoma in 3 , and small cell carcinoma in 2 patients. The post-operative stage of the adenocarcinoma was IA in 60 , IB in 30 , II in 13, IIIA in 11 and IIIB in 5 patients. The patients with adenocarcinoma consisted of 60 males and 59 females, with a mean age of $64.8 \pm 9.0$ years. The mean tumor diameter was $3.2 \pm 1.2 \mathrm{~cm}$. Of the 119 patients, 56 were given UFT.

Preparation of specimens. After lung resection, both normal lung tissue and tumor specimens were obtained and cut into 2 pieces. One was for enzyme immunoassay, and the other was for real-time PCR quantification. They were frozen in liquid nitrogen and stored at $-70^{\circ} \mathrm{C}$ until analysis.

Enzyme-linked immunosorbent assay. The concentrations of TS, DPD and OPRT in cancer tissue were quantified using ELISA in collaboration with Taiho Pharmaceutical Company Research Center (Tokyo, Japan). The measurements were carried out according to the methods previously described (17). In brief, the specimens were homogenized and centrifuged. The supernatant was measured with ELISA using anti-TS (18), anti-DPD (19) and anti-OPRT antibodies (20). The amount of DPD sandwiched with the two anti-DPD monoclonal antibodies (clone 4B9 and 3A5) was estimated by measuring its absorbance at $450 \mathrm{~nm}$. The measured amount of DPD was calibrated with that measured in the standard solutions. Sandwich type ELISA for OPRT was established using anti-OPRT-A and anti-OPRT-C antibodies as the catcher and the tracer, respectively. Protein extract derived from human breast cancer cell line MDA-MB-435S, in which the OPRT protein was previously quantified by immunoblotting, was used as the standard.

\section{Real-time quantitative RT-PCR for TS, DPD and GAPDH} $m R N A$. Quantitative analysis of TS and DPD mRNA levels was performed both in the fresh frozen sample and in the microdissection sample obtained from formalin-fixed tissue.

RNA extraction and cDNA synthesis in the fresh frozen samples. Total RNA was extracted from $100 \mathrm{mg}$ of each tissue sample using an AGPC method. A 1- $\mu \mathrm{g}$ aliquot of total RNA solution including 5 pmol of oligo dT primer in a total volume of $7 \mu \mathrm{l}$ was incubated at $80^{\circ} \mathrm{C}$ for $5 \mathrm{~min}$. After cooling on ice, $8 \mu \mathrm{l}$ of RT-enzyme mixture was added. The RTenzyme mixture contained $3 \mu \mathrm{l}$ of $5 \mathrm{X}$ buffer, $1 \mu 1$ of $0.1 \mathrm{M}$ DTT (Gibco BRL, Carlsbad, CA, USA), $2 \mu 1$ of $2 \mathrm{mM}$ dNTP mixture (PE Applied Biosystems, Foster City, CA, USA), 40 U of RNasin (Promega, Madison, WI, USA) and $200 \mathrm{U}$ of Superscript II reverse transcriptase (Gibco BRL). The resulting mixture was incubated at $42^{\circ} \mathrm{C}$ for $60 \mathrm{~min}$, then denatured at $95^{\circ} \mathrm{C}$ for $5 \mathrm{~min}$.

Real-time quantitative RT-PCR for TS and GAPDH mRNA. PCR reactions were carried out using a reaction mixture containing TaqMan Universal PCR Master Mix (PE Applied Biosystems), the primer mixture, a labeled probe and $1.5 \mu 1$ of sample cDNA that was transcribed from $100 \mathrm{ng}$ of total RNA. The primer mixtures and probes used were $300 \mathrm{nM}$ of TS-F, $900 \mathrm{nM}$ of TS-R1 and $225 \mathrm{nM}$ of TS-Probe for TS mRNA, and $200 \mathrm{nM}$ of GAPDH-F, $200 \mathrm{nM}$ of GAPDH-R, and $100 \mathrm{nM}$ of GAPDH-probe for GAPDH mRNA (Table II). Real-time PCR assays were run on an ABI PRISM 7700 Sequence Detection System (PE Applied Biosystems) with the following protocol: $50^{\circ} \mathrm{C}$ for $2 \mathrm{~min}, 95^{\circ} \mathrm{C}$ for $10 \mathrm{~min}$; and 50 cycles at $95^{\circ} \mathrm{C}$ for $15 \mathrm{sec}$ and $60^{\circ} \mathrm{C}$ for $2 \mathrm{~min}$.

Quantification of mRNA levels. After determination of the threshold cycle $(\mathrm{Ct})$, which was defined as the PCR cycle number at which point the fluorescence intensity exceeds the threshold, the amount of TS mRNA in the sample specimen was calculated from the $\mathrm{Ct}$ of the sample and the RNA 
Table I. Polymerase chain reaction primers and probes used in the microdissection samples.

\begin{tabular}{lcl}
\hline Primer/probe & Length (bp) & \multicolumn{1}{c}{ Sequence } \\
\hline TS2-764F & 18 & GCCTCGGTGTGCCTTTCA \\
TS2-830R & 17 & CCCGTGATGTGCGCAAT \\
Probe TS2-785T & 21 & 6FAM-TCGCCAGCTACGCCCTGCTCA \\
DPD3a-51F & 19 & AGGACGCAAGGAGGGTTTG \\
DPD3a-134R & 20 & GTCCGCCGAGTCCTTACTGA \\
Probe DPD3a-71T & 29 & 6FAM-CAGTGCCTACAGTCTCGAGTCTGCCAGTG \\
OPRT5-496F & 25 & TAGTGTTTTGGAAACTGTTGAGGTT \\
OPRT5-586R & 20 & CTTGCCTCCCTGCTCTCTGT \\
Probe OPRT5-528T & 27 & 6FAM-TGGCATCAGTGACCTTCAAGCCCTCCT \\
B-actin-592F & 18 & TGAGCGCGGCTACAGCTT \\
B-actin-651R & 22 & TCCTTAATGTCACGCACGATTT \\
Probe $3-$-actin-611T & 18 & 6FAM-ACCACCACGGCCGAGCGG \\
\hline
\end{tabular}

F, forward; R, reverse; bp, base pairs.

Table II. The protein level of TS, DPD and OPRT according to pathological stage.

\begin{tabular}{lcccc}
\hline & & TS & DPD & OPRT \\
\hline IA & $(\mathrm{n}=60)$ & $15.3 \pm 29.3$ & $339.5 \pm 179.6$ & $4.7 \pm 1.9$ \\
IB & $(\mathrm{n}=30)$ & $7.8 \pm 5.1$ & $414.2 \pm 396.5$ & $4.2 \pm 2.4$ \\
II+III & $(\mathrm{n}=29)$ & $18.7 \pm 17.4$ & $449.7 \pm 328.7$ & $5.0 \pm 2.1$ \\
Total & $(\mathrm{n}=119)$ & $14.3 \pm 23.3$ & $382.5 \pm 281.4$ & $4.6 \pm 2.1$ \\
\hline
\end{tabular}

Protein levels are expressed as $\mathrm{ng} / \mathrm{mg}$. Values are the mean $\pm \mathrm{SD}$.

standard curve, and then the relationship between the $\mathrm{Ct}$ and the initial standard copy number was expressed as a logarithmic formula. The obtained copy number of TS was then standardized with GAPDH mRNA quantity as the endogenous control using the equation: Result $=\log (\mathrm{TS}$ RNA copy number in tumor)/(GAPDH RNA copy number in tumor) $\mathrm{x}\left(6.1 \times 10^{9}\right.$; GAPDH RNA copy number in $1 \mu \mathrm{g}$ of total RNA extracted from the peripheral blood of 30 healthy volunteers).

Preparation of TS and glyceraldehyde 3-phosphate dehydrogenase standard RNA

Laser capture microdissection (LCM) and RT-PCR. A representative formalin-fixed paraffin-embedded tumor specimen was selected by a pathologist after examination of the hematoxylin and eosin-stained slides. Sections $(10-\mu \mathrm{m})$ were stained with neutral fast red to enable visualization of histology for LCM (P.A.L.M. Microlaser Technologies AG, Munich, Germany). Cancer cells from the sample were dissected using the LCM technique (21). RNA was isolated from these cells using a novel, proprietary procedure (Response Genetics, Los Angeles, CA, USA: US Patent no.
6,248,535). After RNA isolation, cDNA was derived from each sample according to a previously described procedure (22). Target cDNA sequences were amplified by quantitative PCR using a fluorescence-based real-time detection method [ABI PRISM 7900 Sequence Detection System (Taqman); Applied Biosystems] as previously described $(23,24)$. The 25- $\mu 1 \mathrm{PCR}$ reaction mixture contained $600 \mathrm{nmol} / 1$ of each primer (Table I), $200 \mathrm{nmol} / \mathrm{l}$ each of dATP, dCTP and dGTP, $400 \mu \mathrm{mol} / 1 \mathrm{dUTP}, 5.5 \mathrm{mmol} / 1 \mathrm{MgCl}_{2}$, and $1 \mathrm{X}$ TaqMan buffer A containing a reference dye (all reagents from Applied Biosystems). The PCR conditions were $50^{\circ} \mathrm{C}$ for $10 \mathrm{sec}$ and $95^{\circ} \mathrm{C}$ for $10 \mathrm{~min}$, followed by 42 cycles at $95^{\circ} \mathrm{C}$ for $15 \mathrm{sec}$ and $60^{\circ} \mathrm{C}$ for $1 \mathrm{~min}$. TS, DPD and TP gene expression in each part of the tumor was quantified as ratios between two absolute measurements (gene of interest/ß-actin).

Immunohistochemical staining for TS and DPD. Paraffinembedded specimens were cut into $5-\mu \mathrm{m}$ sections, and the slides were autoclaved for $10 \mathrm{~min}$ in the target retrieval solution with $0.01 \mathrm{~mol} / 1$ Tris buffer, $0.001 \mathrm{~mol} / 1$ EDTA (pH 9.0), and $0.01 \mathrm{~mol} / \mathrm{l}$ citrate buffer. Anti-TS (polyclonal rabbit antihuman recombinant TS; Tokyo, Japan) and anti-DPD (monoclonal mouse anti-human CD5, NCL-CD5-4C7; Mitsubishi Kagaku Iatron, Tokyo, Japan) were used as primary antibodies. Serial sections were incubated with primary antibodies for 60 min followed by incubation with biotinylated anti-rabbit or anti-mouse immunoglobulin. After secondary antibody application, streptavidin-horseradish-peroxidase conjugate was applied. The complex was visualized with 3,3 diaminobenzidene and enhanced with copper sulfate. The degree of immunostaining was scored as follows by one pathologist (H.U.) who was blinded to the patient information: -, no staining; scattered, staining of $<30 \%$ of tumor cells; and diffuse, staining of $\geq 30 \%$ of tumor cells. Negative and positive controls were included in each batch.

For TS activity, the FdUMP binding assay, and for DPD activity, the DPD catalytic assay were performed based upon 
Comparison of mRNA levels of TS and DPD in each sample

TS mRNA

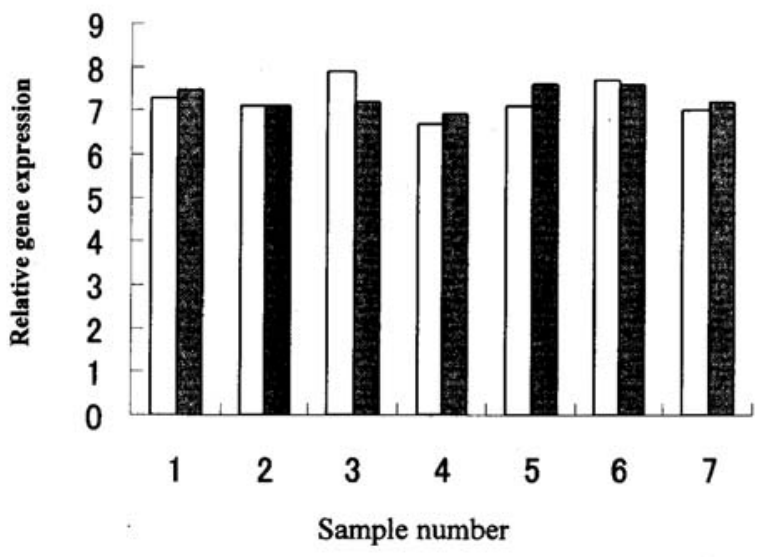

DPD mRNA

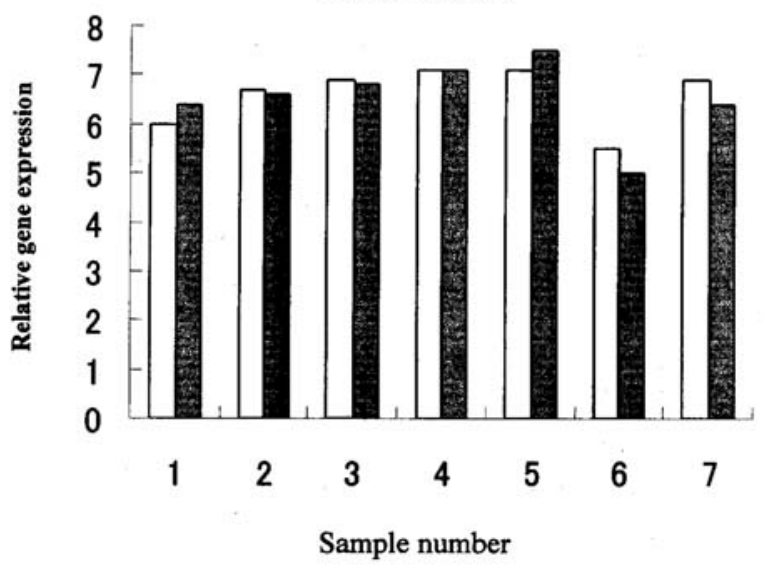

Figure 1. Messenger RNA expression of TS and DPD in 7 individual patients. Messenger RNA expression of the cancer tissue from different parts was essentially the same. The paired t-test for TS and DPD in each patient was not significant ( $\mathrm{p}=0.774$ for $\mathrm{TS}, \mathrm{p}=0.696$ for DPD). The messenger level was expressed as relative gene expression.

the method described by Takechi et al (25). Briefly, aliquots of the prepared sample $(25 \mu \mathrm{l})$ were mixed with $25 \mu \mathrm{l}$ of enzyme reaction mixture $\left(2 \mathrm{mM}\right.$ dithiothreitol, $5 \mathrm{mM} \mathrm{MgCl}_{2}$, $20 \mu \mathrm{M}\left[6-{ }^{14} \mathrm{C}\right] 5-\mathrm{FU}, 100 \mu \mathrm{M}$ NADPH), incubated at $37^{\circ} \mathrm{C}$ for $30 \mathrm{~min}$, and applied to thin-layer chromatography plates (silica gel 60 F254; Merck, Darmstadt, Germany). DPD activity was determined by measuring the sum of the dihydrofluorouracil and 2-fluoro- $\$$-alanine products formed from $\left[6-{ }^{14} \mathrm{C}\right] 5-\mathrm{FU}$. The plates were developed with a mixture of ethanol and $1 \mathrm{M}$ ammonium acetate $(5: 1, \mathrm{v} / \mathrm{v})$, according to the method of Ikenaka et al (26). 5-FU and the catabolized products formed from 5-FU were visualized and quantified using an image analyzer (BAS-2000, Fujix, Tokyo, Japan).

Statistical analysis. Data were expressed as the mean \pm standard deviation. Comparisons of the mean values within groups were carried out using one-way ANOVA. When ANOVA was significant, the Tukey's test was used for post hoc multiple
A Activity $=-57.596+1.604$ * ELISA

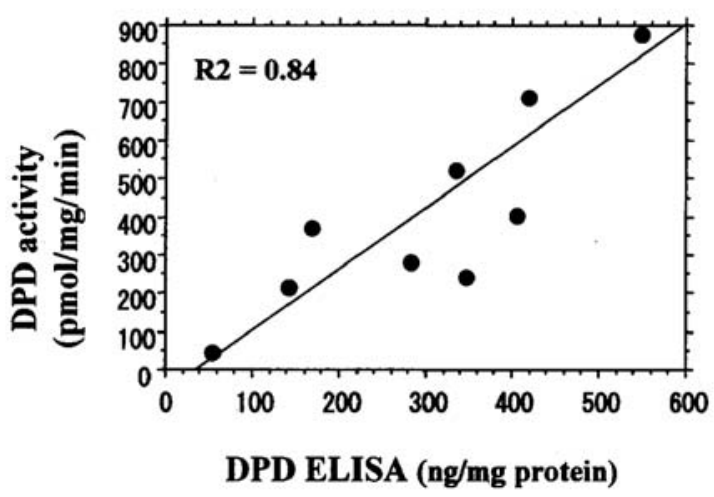

B $\quad$ mRNA $=6.407+.178$ * microdissection

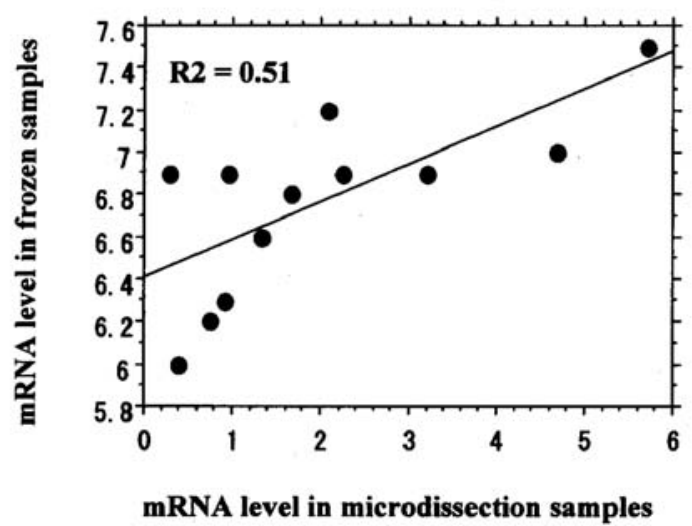

Figure 2. (A) Correlation of protein level and enzyme activity. The DPD level measured by ELISA was significantly correlated with DPD activity in a linear fashion $\left(\mathrm{R}^{2}=0.842\right)$. (B) Correlation of gene expression in fresh frozen specimens and formalin-fixed slides. Correlation for DPD was relatively high $\left(\mathrm{R}^{2}=0.511\right)$. The messenger level was expressed as relative gene expression. comparisons between groups. The correlation between the protein level of DPD measured by ELISA and the enzymatic activity of DPD was tested using linear regression analysis. Association of variables for TS and DPD was evaluated using the paired t-test. For all analyses, a p-value of $<0.05$ was considered statistically significant. All analyses were performed using SPSS 13.0J (SPSS Japan Inc., Tokyo, Japan) and SAS 8.2 (SAS Institute Inc., Cary, NC, USA).

\section{Results}

To exclude sampling bias of the tumor tissue, a pilot study was carried out using samples from 7 patients with adenocarcinoma. The tumor was cut in half at the maximum diameter, and specimens were obtained from 2 different areas of the tumor. Each sample was analyzed for messenger RNA expression. Fig. 1 demonstrates the messenger RNA expression of TS and DPD in 7 individual patients. The messenger RNA 


\section{Correlation of protein level and mRNA level in microdissection samples}
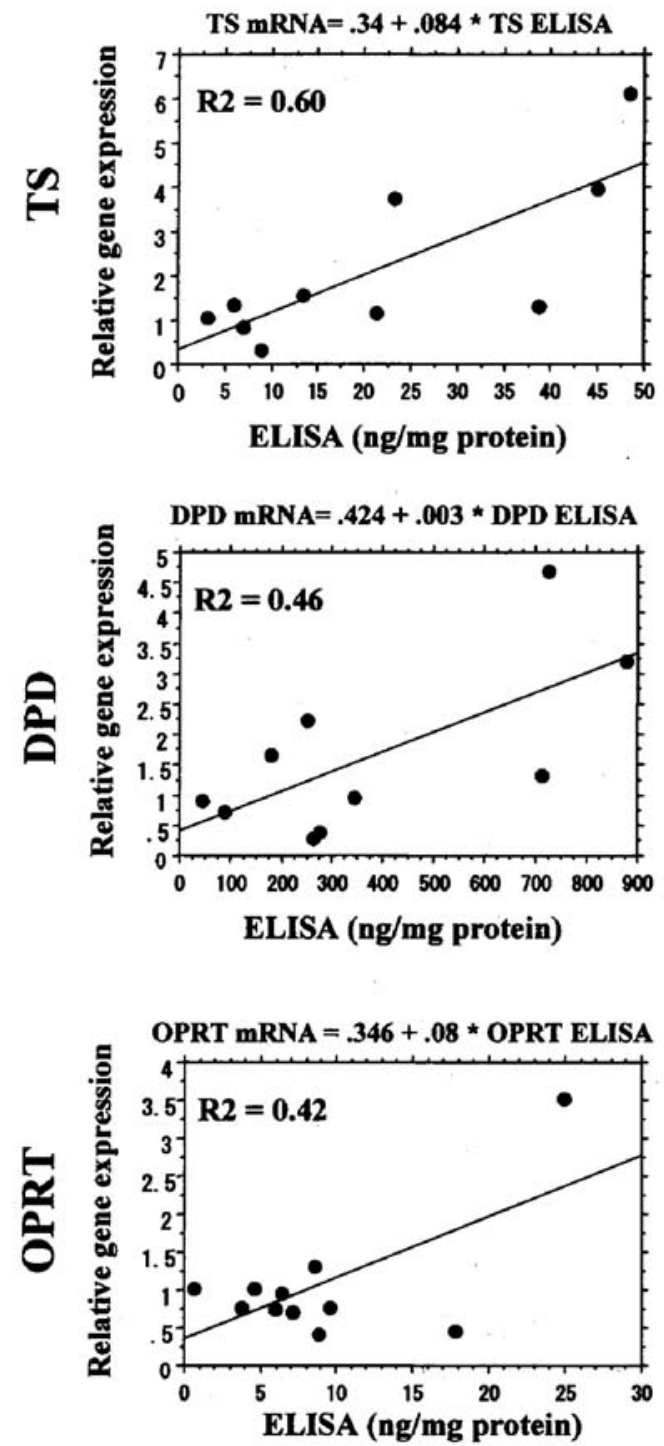

Figure 3. Correlation of gene expression in microdissection samples and ELISA level. The messenger level was expressed as relative gene expression.

expression of the cancer tissue from different parts was essentially the same. The paired t-test for TS and DPD in each patient was not significant ( $\mathrm{p}=0.774$ for TS, $\mathrm{p}=0.696$ for DPD). Thus, we decided to obtain 2 specimens from the center of the tumor. One was for enzyme immunoassay, and the other was for real-time PCR quantification.

The data obtained by measurements with 4 different methods in each sample were then compared: gene expression measured by real-time PCR using fresh frozen samples, gene expression in microdissection samples, protein expression measured by ELISA, and enzyme activity for DPD. Since the amount of the samples was insufficient for all enzyme measurements, we focused on DPD. Of the 4 independent methods, the highest correlation was observed between ELISA and enzyme activity. The DPD level measured by ELISA was significantly correlated with DPD activity in a linear
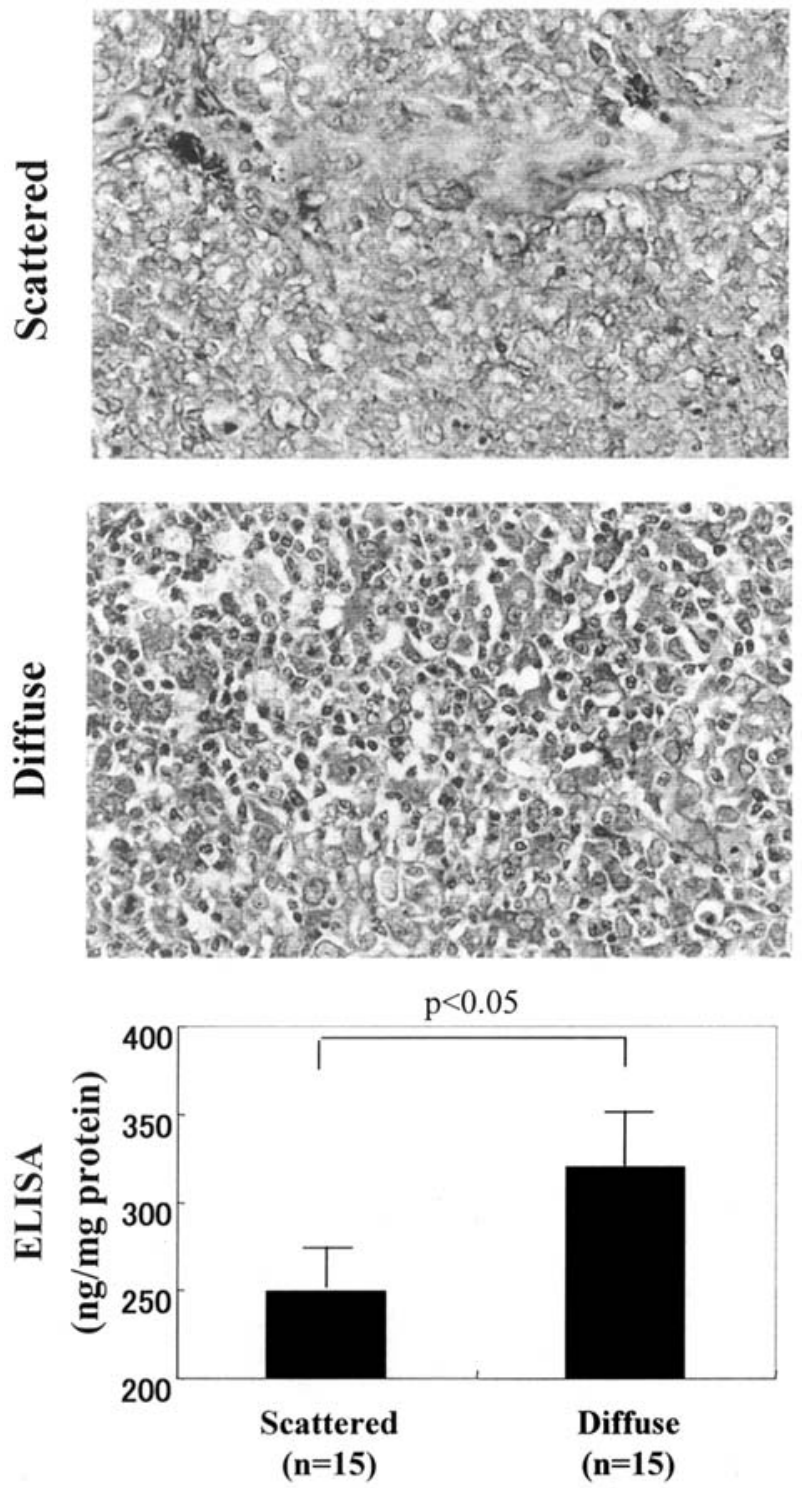

Immunohistochemistry

Figure 4. Representative staining of DPD (upper, middle) and the mean protein level measured by ELISA (lower). The mean protein level of DPD in samples with a scattered staining pattern was significantly lower than that in samples with a diffuse staining pattern.

fashion $\left(\mathrm{R}^{2}=0.842\right.$, Fig. $\left.2 \mathrm{~A}\right)$. The correlation between the gene expression of fresh frozen samples and that of microdissection samples obtained from formalin-fixed paraffin samples for DPD was relatively high $\left(\mathrm{R}^{2}=0.511\right.$, Fig. $\left.2 \mathrm{~B}\right)$. The correlation between gene expression of microdissection samples and protein expression measured by ELISA was also significant for TS, DPD and OPRT (Fig. 3). A close correlation was also observed between ELISA and immunohistochemical staining for DPD. Fig. 4 shows representative staining for DPD and the mean protein level measured by ELISA. The mean protein level of DPD in samples with a scattered staining pattern was significantly lower than that in samples with a diffuse staining pattern.

Finally, the protein level was measured by ELISA in 119 adenocarcinomas. The level of each enzyme in all stages was $14.3 \pm 23.3 \mathrm{ng} / \mathrm{mg}$ protein for $\mathrm{TS}, 382.5 \pm 281.4 \mathrm{ng} / \mathrm{mg}$ protein 
for DPD, and $4.6 \pm 2.1 \mathrm{ng} / \mathrm{mg}$ protein for OPRT (Table II). There was no significant correlation between the TS, DPD and OPRT levels and the pathological stage. There were 3 patients with recurrence among the 90 patients with pathological stage I adenocarcinoma. Two were stage IA patients who did not receive UFT, and one was a stage IB patient who received UFT. The predictive value of the enzymes for prognosis and the effectiveness of 5-FU could not be determined because few recurrences were observed during the short follow-up period.

\section{Discussion}

Measurement of gene expression by RT-PCR is a useful technique for a small size sample. Among several techniques for quantification of gene expression, cancer cell-specific measurement is of great interest, since the target of adjuvant chemotherapy with 5-FU may be micrometastases after radical surgery, and the expression of 5-FU-related enzymes in the tumor cell may predict the value of chemotherapy. Recently, Danenberg and colleagues developed a method to quantify mRNA levels of enzymes in cancer cells (27-30). The cancer cells were selectively harvested from paraffinembedded samples by laser capture microdissection. Using this technique, gene expression of 5-FU metabolic enzymes in breast (27), colorectal (28), gastric (29) and pancreatic cancer (30) was reported. Kakimoto et al (27) measured TS, DPD and thymidine phosphorylase (TP) mRNA levels separately in cancer cells, cancerous stroma and normal glands in breast cancer patients. They demonstrated that the group with low TS and low DPD expression in cancer cells was sensitive to 5-FU. Kodera et al (28) measured mRNA levels of four 5-FU metabolic enzymes and concluded that the mRNA level of OPRT may have a major impact on drug sensitivity in gastric cancer patients. Kuramochi et al (29) reported that the intratumoral DPD mRNA expression level was significantly higher in pancreatic cancer than in other malignancies. These reports emphasize the usefulness of cancer cell-specific measurement. Although cancer-specific measurement is an ideal technology, it requires sophisticated techniques. Furthermore, messenger expression does not always represent protein expression and functions. On the other hand, enzyme activity directly reflects protein functions. Enzyme activity for 5-FU-related enzymes was measured by FdUMP binding assay for TS and radio-enzymatic assay for DPD. However, both methods require a larger sample, depend on the quality of stored samples, and require radioisotopes. Thus, a simple method using small samples is required for prediction of response to 5-FU therapy.

With respect to protein expression measured by ELISA, limited information is available. Protein levels of TS and DPD were measured by ELISA in non-small cell lung cancer tissues (31), gastric cancer (32), and gastrointestinal cancer culture cells (33). Nishina et al (32) measured DPD and TP by ELISA in biopsy samples from patients with gastric cancer. Chujo et al (31) measured TP and DPD levels in lung cancer tissue and demonstrated that the ratio of the TP level to the DPD level was higher in squamous cell carcinoma than in adenocarcinoma. They concluded that 5-FU may be more effective in squamous cell carcinoma. Using cancer cell lines,
Ma et al (33) demonstrated a good correlation between protein levels and RT-PCR product intensity both for TP and DPD.

In the present study, the protein level measured by ELISA correlated highly with the enzyme activity of DPD. As gene expression of microdissection samples correlated with ELISA results not only for DPD but also for TS and OPRT, the protein level measured by ELISA may represent messenger expression of the tumor cells and enzyme activity for both TS and OPRT. To the best of our knowledge, the present study is the first to show a good correlation between protein expression measured by ELISA and enzyme activity and gene expression in lung cancer tissue. Upon immunohistochemistry, the protein level of DPD with a diffuse staining pattern clearly indicated a high level of protein expression (Fig. 4). Thus, ELISA appears to be a simple and reliable method to represent enzyme activity and messenger expression of the tumor cell.

The DPD level of lung cancer tissue in the present study was much higher than that in previous reports dealing with breast, colorectal and gastric cancer (34). A high DPD level may be related to resistance of lung cancer to 5-FU therapy. The use of UFT or S-1 (oral fluoropyrimidine derivative consisting of tegafur and two modulators, 5-chloro-2,4dihydroxypyrimidine and potassium oxonate) may be a reasonable strategy in lung cancer.

In summary, 5-FU-related enzymes were measured using different methods, and the relationships between pairs of results were compared. Protein levels measured by ELISA correlated with both enzymatic activity and mRNA expression. These results may be important to establish the predictive value of 5-FU-related enzymes.

\section{Acknowledgements}

We thank Taiho Pharmaceutical Co. Ltd. for the technical assistance in the determination of TS, DPD and OPRT levels.

\section{References}

1. Kato H, Ichinose Y, Ohta M, Hata E, Tsubota N, Tada H, Watanabe Y, Wada H, Tsuboi M, Hamajima N, Ohta M, Japan Lung Cancer Research Group on Postoperative Adjuvant Chemotherapy: A randomized trial of adjuvant chemotherapy with uracil-tegafur for adenocarcinoma of the lung. $\mathrm{N}$ Engl $\mathrm{J}$ Med 350: 1713-1721, 2004

2. Hamada C, Tanaka F, Ohta M, Fujimura S, Kodama K, Imaizumi $\mathrm{M}$ and Wada $\mathrm{H}$ : Meta-analysis of postoperative adjuvant chemotherapy with tegafur-uracil in non-small-cell lung cancer. J Clin Oncol 23: 4999-5006, 2005.

3. Nakagawa M, Tanaka F, Tsubota N, Ohta M, Takao M, Wada H. West Japan Study Group for Lung Cancer Surgery: A randomized phase III trial of adjuvant chemotherapy with UFT for completely resected pathological stage I non-small-cell lung cancer: the West Japan Study Group for Lung Cancer Surgery (WJSG) - the 4th study. Ann Oncol 16: 75-80, 2005.

4. Rustum YM, Harstick A, Cao S, Vanhoefer U, Yin MB, Wiike H and Seeer S: Thymidine synthase inhibitors in cancer therapy: direct and indirect inhibitors. J Clin Oncol 15: 389-400, 1997.

5. Beck A, Etienne MC, Cheradame S, Fischel JL, Formento P, Renee N and Milano G: A role of dihydropyrimidine dehydrogenase and thymidylate synthase in tumour sensitivity to fluorouracil. Eur J Cancer 30A: 1517-1522, 1994.

6. Heggie GD, Sommandossi P, Cross DS, Huster WJ and Diasio RB: Clinical pharmacokinetics of 5-fluorouracil and its metabolites in plasma, urine, and bile. Cancer Res 47: 2203-2206, 1987. 
7. Ichikawa W, Uetake H, Shirota Y, Yamada H, Takahashi T, Nihei Z, Sugihara K, Sasaki Y and Hirayama R: Both gene expression for orotate phosphoribosyltransferase and its ratio to dihydropyrimidine dehydrogenase influence outcome following fluoropyrimidine-based chemotherapy for metastatic colorectal cancer. Br J Cancer 89: 1486-1492, 2003.

8. Ichikawa W, Uetake H, Shirota Y, Yamada H, Nishi N and Nihei Z: Combination of dihydropyrimidine dehydrogenase and thymidylate synthase gene expressions in primary tumors as predictive parameters for the efficacy of fluoropyrimidine-based chemotherapy for metastatic colorectal cancer. Clin Cancer Res 9: 786-791, 2003

9. Salonga D, Danenberg KD, Johnson M, Metzger R, Groshen S, Tsao-Wei DD, Lenz HJ, Leichman CG, Leichman L, Diasio RB and Danenberg PV: Colorectal tumors responding to 5fluorouracil have low gene expression levels of dehydropyrimidine dehydrogenase, thymidylate synthase, and thymidine phosphorylase. Clin Cancer Res 6: 1322-1327, 2000.

10. Fujiwara H, Terashima M, Irinoda T, Takagane A, Abe K, Kashiwaba M, Oyama K, Takahashi M, Maesawa C, Saito K, Takechi T and Fukushima M: Quantitative measurement of thymidylate synthase and dihydropyrimidine dehydrogenase mRNA level in gastric cancer by real-time RT-PCR. Jpn J Cancer Res 93: 1342-1350, 2002.

11. Higashiyama M, Kodama K, Yokouchi H, Takami K, Fukushima M, Minamigawa K, Takano T and Kobayashi H: Thymidylate synthase and dihydropyrimidine dehydrogenase activities in non-small cell lung cancer tissues: relationship with in vitro sensitivity to 5-fluorouracil. Lung Cancer 34: 407-416, 2001.

12. Shintani Y, Ohta M, Hirabayashi H, Tanaka H, Iuchi K, Nakagawa K, Maeda H, Kido T, Miyoshi S and Matsuda H: Thymidylate synthase and dihydropyrimidine dehydrogenase mRNA levels in tumor tissues and the efficacy of 5-fluorouracil in patients with non-small-cell lung cancer. Lung Cancer 45: 189-196, 2004

13. Inoue K, Takao M, Watanabe F, Tarukawa T, Shimamoto A, Kaneda M, Sakai T, Fukushima M, Shimpo H and Yada I: Role of dihydropyrimidine dehydrogenase inhibitory fluoropyrimidine against non-small cell lung cancer - in correlation with the tumoral expression of thymidylate synthase and dihydropyrimidine dehydrogenase. Lung Cancer 49: 47-54, 2005

14. Oguri T, Achiwa H, Bessho Y, Muramatsu H, Maeda H, Niimi T, Sato $\mathrm{S}$ and Ueda R: The role of thymidylate synthase and dihydropyrimidine dehydrogenase in resistance to 5-fluorouracil in human lung cancer cells. Lung Cancer 49: 345-351, 2005.

15. Nakano J, Huang C, Liu D, Masuya D, Nakashima T, Yokomise H, Ueno M, Wada H and Fukushima M: Evaluations of biomarkers associated with 5-FU sensitivity for non-small-cell lung cancer patients postoperatively treated with UFT. Br J Cancer 95: 607-615, 2006

16. Locker GY, Hamilton S, Harris J, Jessup JM, Kemeny N, Macdonald JS, Somerfield MR, Hayes DF, Bast RC Jr; ASCO: ASCO 2006 update of recommendations for the use of tumor markers in gastrointestinal cancer. J Clin Oncol 24: 5313-5327, 2006.

17. Kurebayashi J, Yamamoto Y, Udagawa K, Okubo S, Fukushima M and Sonoo H: Establishment of enzyme-linked immunosorbent assays for thymidylate synthase and dehydropyrimidine dehydrogenase in cancer tissues. Oncol Rep 11: 973-979, 2004.

18. Okabe H, Tsujimoto H and Fukushima M: Preparation of the antibodies against recombinant human thymidylate synthase for the detection of its intratumoral levels and the application to sensitivity-study of 5-fluorouracil. Oncol Rep 4: 685-690, 1997.

19. Podschun B, Wahler G and Schnackerz KD: Purification and characterization of dihydropyrimidine dehydrogenase from pig liver. Eur J Biochem 185: 219-224, 1989.
20. Sakamoto K, Sugimoto Y, Miyadera K, Oka T and Fukushima M: Preparation of anti-orotate phosphoribosyltransferase antibody and its application to immunochemical detection in human tumor cells. Int J Mol Med 16: 245-249, 2005.

21. Bonner RF, Emmert-Buck M, Cole K, Pohida T, Chuaqui R, Goldstein S and Liotta LA: Laser capture microdissection: molecular analysis of tissue. Science 278: 1481-1483, 1997.

22. Lord RV, Salonga D, Danenberg KD, Peters JH, DeMeester TR, Park JM, Johansson J, Skinner KA, Chandrasoma P, DeMeester SR, Bremner CG, Tsai PI and Danenberg PV: Telomerase reverse transcriptase expression is increased early in the Barrett's metaplasia, dysplasia, carcinoma sequence, J Gastrointest Surg 4: 135-142, 2000

23. Heid CA, Stevens J, Livak KJ and Williams PM: Real time quantitative PCR. Genome Res 6: 986-994, 1996.

24. Gibson UE, Geid CA and Williams PM: A novel method for real time quantitative RT-PCR. Genome Res 6: 995-1011, 1996.

25. Takechi T, Uchida J, Fujioka A and Fukushima M: Enhancing 5-fluorouracil cytotoxicity by inhibiting dihydropyrimidine dehydrogenase activity with uracil in human tumor cells. Int J Oncol 11: 1041-1044, 1997.

26. Ikenaka K, Shirasaka T, Kitano S and Fujii S: Effect of uracil on metabolism of 5-fluorouracil in vitro. Gann 70: 353-359, 1979.

27. Kakimoto M, Uetake H, Osanai T, Shirota Y, Takagi Y, Takeshita E, Toriya Y, Danenberg K, Danenberg PV and Sugihara K: Thymidylate synthase and dihydropyrimidine dehydrogenase gene expression in breast cancer predicts 5-FU sensitivity by a histocultural drug sensitivity test. Cancer Lett 223: 103-111, 2005.

28. Kodera Y, Ito S, Fujiwara M, Mochizuki Y, Nakamura G, Ohashi N, Koike M, Yamamura Y and Nakao A: Gene expression of 5-fluorouracil metabolic enzymes in primary gastric cancer: Correlation with drug sensitivity against 5-fluorouracil. Cancer Lett 252: 307-313, 2007.

29. Kuramochi H, Hayashi K, Uchida K, Nakajima G, Hatari T, Danenberg D, Danenberg PV and Yamamoto M: High intratumoral dihydropyrimidine dehydrogenase mRNA levels in pancreatic cancer associated with a high rate of response to $\mathrm{S}-1$. Cancer Chemother Pharmacol 63: 85-89, 2008.

30. Kuramochi H, Hayashi K, Uchida K, Miyakura S, Shimizu D, Vallbohmer D, Park S, Danenberg K, Takasaki K and Danenberg PV: 5-Fluorouracil-related gene expression levels in primary colorectal cancer and corresponding liver metastasis. Int J Cancer 119: 522-526, 2006.

31. Chujo M, Miura T, Kawano Y, Miyazaki M, Imakiire T, Hayashita Y and Kawahara K: Thymidine phosphorylase levels and dihydropyrimidine dehydrogenase levels in non-small cell lung cancer tissues. Oncol Rep 16: 777-780, 2006.

32. Nishina T, Hyodo I, Miyaike J, Inaba T, Suzuki S and Shiratori Y: The ratio of thymidine phosphorylase to dihydropyrimidine dehydrogenase in tumor tissues of patients with metastatic gastric cancer is predictive of the clinical response to 5'-deoxy5-fluorouridine. Eur J Cancer 40: 1566-1571, 2004.

33. Ma T, Zhu ZG, Ji YB, Zhang Y, Yu YY, Liu BY, Yin HR and Lin YZ: Correlation of thymidylate synthase, thymidine phosphorylase and dihydropyrimidine dehydrogenase with sensitivity of gastrointestinal cancer cells to 5-fluorouracil and 5-fluoro-2'-deoxyuridine. World J Gastroenterol 10: 172-176, 2004.

34. Mori K, Hasegawa M, Nishida M, Toma H, Fukuda M, Kubota T, Nagasue N, Yamana H, Chung KH, Ikeda T, Takasaki K, Oka M, Kameyama M, Toi M, Fujii H, Kitamura M, Murai M, Sasaki H, Ozono S, Makuuchi H, Shimada Y, Onishi Y, Aoyagi S, Mizutani K, Ogawa M, Nakao A, Kinoshita H, Tono T, Imamoto H, Nakashima Y and Manabe T: Expression levels of thymidine phosphorylase and dihydropyrimidine dehydrogenase in various human tumor tissues. Int J Oncol 17: 33-38, 2000. 